\title{
Comparative Analysis of the effectiveness of Project and Conventional Extension Approaches on Levels of Maize Production among Smallholder Farmers, A Case of One-Acre Fund in Seme Sub-County, Kenya
}

Otieno Stephen Otieno ${ }^{1 *}$, David K. Bun
$\begin{aligned} & { }^{1} \text { Department of Agricultural Education and Exten } \\ & { }^{2-3} \text { School of Agriculture and Natural Resource M } \\ & \text { Article History } \\ & \text { Received: } 18.01 .2021 \\ & \text { Accepted: } 21.03 .2021 \\ & \text { Published: } 26.03 .2021\end{aligned}$
http://www.easpublisher.com

\author{
unyatta $^{2}$, Evans A. Basweti $^{3}$
}


dissemination for adoption, resulting into increased maize production.

An effective extension approach is a very important factor towards sustainable agricultural development among the small-scale farmers since it enhances effective technologies delivery for uptake. Hence, by improving, the productive capacity of these smallholder farmers through effective extension systems not only improves their food security and livelihood but also contribute towards national economic growth. Improved productivity, improved rural livelihoods, increased food security and better growth is realized when agricultural extension systems are well designed and implemented [6-8]. This study recognises the influence of selected extension approaches on maize production levels.

In Kenya, the County Governments and private sectors have adopted several extensions approaches to enhance the dissemination of improved agricultural technologies for adoption by smallholder farmers to increase level of maize production in terms of yields. Such extension approaches include project and conventional extension approaches, which this study considered while comparing their effectiveness.

\section{Problem statement}

In Kenya, maize is a staple food for many rural households. Availability and accessibility of agricultural extension services is vital for adoption of improved agricultural technologies as it bridges the gap of lack of years of formal education [9]. Extension services avail avenues for the acquisition of knowledge about new technologies and important information meant to promote adoption of technologies. Effectiveness of an agricultural extension approach is crucial during the process of dissemination and adoption of improved agricultural technologies among small-scale farmers. Whenever, these improved agricultural technologies are adopted, agricultural production increases resulting into enhanced household food security and improve food nutrition.

The Ministry of Agriculture in Kisumu County for a long period has adopted conventional extension approach for dissemination of selected maize production technologies among small-scale farmers for adoption in the study area. However, this conventional extension approach has not improved much the yield of maize in terms of its production level per acre. The One Acre Fund project, which was initiated in the year 2014, introduced project extension approach as an alternative of this conventional extension approach, which has succeeded minimally in increasing maize production in the study area. Since the introduction of the project, extension approach there has been no study to compare the two approaches in terms of their effectiveness on maize production levels among the small-scale farmers in the study area.

\section{Conceptual Clarification \\ Extension Approaches}

An "extension approach" according to MOALD, [16] is a style or strategy of managing extension. According Maunder [15] extension can be termed as a continuous process of delivering important information to the beneficiaries, assisted them to get necessary and relevant skills, knowledge and attitude to utilise the information or techniques for their own benefit. This study focused on project extension approach and conventional extension approach.

\section{Project Extension Approach}

In this approach, the outside resources for a specific period are concentrated on a location and focuses on improving livelihood of the targeted population with the hope that adjacent populations will learn from the benefiting group. It always uses group extension methods such as demonstrations. Dissemination of knowledge and skills can occur in meetings to expound matter related to maize production technologies. In this approach, trainings are best carried out on individual farms with two kinds of demonstration; a) method demonstrations involving showing farmers how task or activity is executed. It is regarded as an effective method as beneficiaries or farmers can hear, see, practice and discuss while demonstration is ongoing; b) result demonstrations which involves farmers being shown the results of a concluded practice with intention to arouse the farmer's interest in the practice.

\section{One Acre Fund}

This is a social enterprise operating in Kenya (https://oneacrefund.org/about-us/) reaching approximately 408,000 small scale farmers by 2019 (https://oneacrefund.org/2019-annual-report/) and nonprofit in nature aimed at enhancing agricultural productivity for poverty reduction among smallholder farmers on staples food crops such as (e.g., maize, some beans). Through market-based model, small scale farmers receive complete bundle of services aimed doubling their incomes per planted acre. The model comprises of; loans inform of farm inputs with flexible repayment system; delivery of inputs to farmers they serve; Training of farmers on modern agricultural technologies; crop storage solutions and capacity building farmers about maximizing profits despite dynamic forces in the market. The program since the year 2015 utilizes project extension approach to train farmers on modern agricultural practices for various crops including maize. This study targeted small holder farmers who are beneficiaries of the approach between the years 2015 to 2018 .

\section{Conventional Extension Approach}

Also known as Ministry-Based general extension approach and based on the premise that technologies, innovations, and information are suitable to the local farming conditions are available. However, 
smallholder farmers are not making full utilization of the improved technologies, and information to improve their farming situation. In this approach most decisions on the management and major controls of the approach is controlled at the government headquarters. This makes the extension approach more centralized and government controlled. Improvement in national production and adoption rate of recommended technologies are regarded as the success indicators. This approach has been widely criticised for not being efficient and effective by not achieving its objectives of; effectively improving adoption rates and increasing national production. High levels of bureaucracy and hierarchical procedures experienced in this approach is considered as the cause of its inefficiency. This study also targeted small holder farmers who are beneficiaries of the approach between the year 2015 to 2018 .

\section{Level of Maize production}

Domesticated in Central America some 6,000 to 10,000 years ago, maize crop has spread to the rest of the world in the 16th through 18th centuries. According to Morris [16], white maize plays a major role in the diet in sub-Saharan Africa and Central America and maize production is connected to technology in the global perspective.

Maize is an important staple food crop in Kenya and contributes more than $25 \%$ of agricultural employment and $20 \%$ of total agricultural production [2]. According to Karanja [17], maize is as a major food, employment and source of income for majority of rural households. Welfare and food security of the farming population are dependent on the productive capacity of maize farmers. More than $70 \%$ of maize area in Kenya is cultivated on farms of less than 20 acres [17]. Adoption of maize agricultural technologies by farmers have the potential of improving maize production. Most farmers in the study area do plant their maize crop without following the recommended agronomic practices but from many studies, whenever the recommended agronomic practices are applied, yields are observed to increase under favourable weather conditions. For example, in the past 50 years, there has been a dramatic increase in agricultural production following the use of chemical fertilizers and high yielding seed varieties [18]. Through fertilisers' application, all required micro and macronutrients are availed to maize to boost production. According to Sanchez et al., [4], proper fertilizers application is evident to contribute to larger extent sustained crop productivity. According to Kolawole [19], crop production is also influenced by the time and rate of fertiliser's application.
Most farmers in the study area use local maize varieties, but in this project improved maize seed varieties were availed for adoption. Maize hybrid seeds avails to farmers' varieties containing improved genetics such high yielding potential and strengthened resistance towards pest and diseases. Likewise, in subSaharan Africa, adoption of improved maize is indicated to have positive outcomes on maize production [20]. Spacing of plants within a row can change the amount of light available for the plants; with reduced light competition from the plants, increment in total crop yield can be realized [21].

According to Spasojevic [22] maize plant, physiological process and morphology are modified by weed competition, which in turns affects their light use efficiency and physiological processes relevant for their productivity such as chlorophyll and carotenoids contents. Maize yields are greatly affected by weeds in the field. They compete with maize crop for moisture, space, light and nutrients and consequently interfere with normal growth of maize. Weed control is therefore vital for maize production and if not correctly checked yield loss can be closed to $39.8 \%$ [23]. Farmers in the study project were encouraged to undertake proper and timely weeding; that is twice per season.

Whenever, a recommended maize seed rate is applied per hole/hill, the maize production is observed to increase. Post-harvest handling of maize produce has a remarkable influence on the food nutrition security at household levels, through utilization of improved maize storage bags and use of maize storage chemical like actellic gold dust, the grain quality is maintained for a long time due to reduced exposure to loss causative agents such as moisture contamination and weevil attack.

\section{Methodology Study Area}

This study was undertaken within East Seme Location in Seme Sub-County, which borders Kisumu West to the East, Rarieda to the West and Lake Victoria to the South. The area lies on a GPS position of Latitude. $\quad-0.0833^{\circ} \mathrm{S}, \quad$ Longitude. $34.5167^{\circ} \mathrm{E}$ with elevation of $1,300 \mathrm{~m}$. Seme Sub County population stands at 121,667 according to National Census of 2019 and covers an area of $268 \mathrm{Sq}$. Km. The study was conducted in Kaila Sub Location with a population of 4,681 according to 2019 National Census Report. The area experiences an average temperature of $22.9^{\circ} \mathrm{C}$ and average rainfall of $1,321 \mathrm{~mm}$ annually with January being the driest month and April being the highly rainfall month. The area under maize production is averagely 8,000 ha in Long rains and 3,500ha in short rains. The area averagely produces $2,250 \mathrm{~kg} / \mathrm{ha}$ during the long rains and $1,800 \mathrm{~kg} / \mathrm{ha}$ in short rains. 


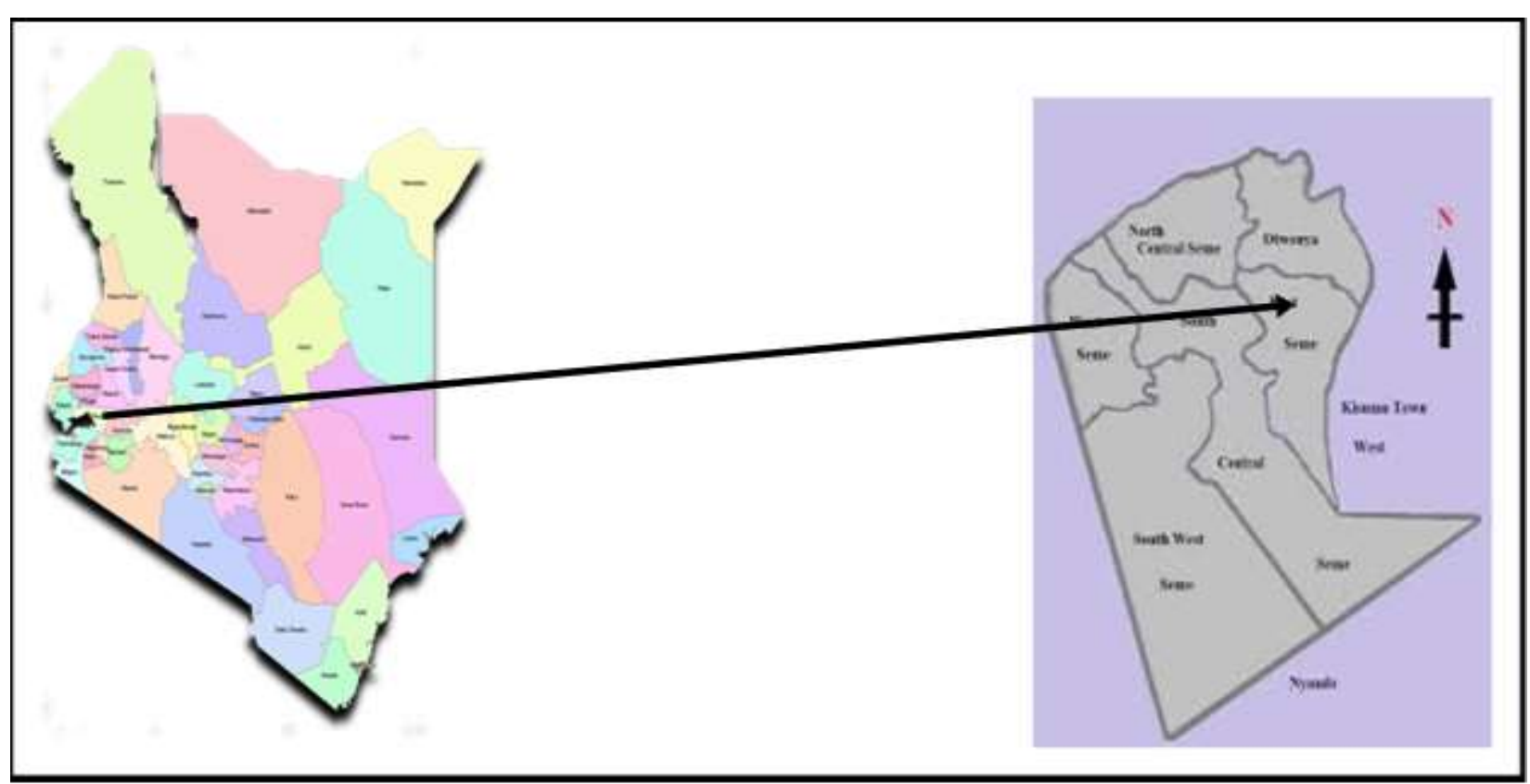

Fig-1: The Map of Kenya Showing the study area in Kisumu County Source: IEBC 2009,

\section{Research Design}

This study employed survey research method with an ex-post facto research design; the choice of this research design was adopted because it allows the investigator (s) to conduct the study after the fact has occurred without necessarily interfering with the variables [10]. Ex-post facto is ideal especially when the variables being studied are not manipulated, but studied in their natural context Wiersma, [11]. According to Kothari [12], he argues that Ex-post facto research design may be used to assess relationships between previous and past events.

\section{Target Population}

The study targeted 142 small scale farmers who were project beneficiaries for a period of 4 years. The study also targeted beneficiaries of conventional extension approach from the extension services of Ministry of Agriculture under Kisumu County Government during the same period. The targeted individual maize farmers were subjected for face to face interviews using a semi structured questionnaire. Both qualitative and quantitative data was used to analyze the data.

\section{Sampling Techniques and Sample Size Determination}

Simple random and purposive sampling methods were employed. Simple random sampling was used to select project and conventional extension approaches beneficiaries. Purposive sampling was used to select project extension approach beneficiaries and they were purposively chosen on the basis of who meets the purpose of the study at its best. The study therefore applied Cochran's formula [13] to give a representative sample size of 180 respondents, which was distributed as shown in Table1 below.

Using Cochran's sample size formula of:

$\mathrm{N} 0=(\mathrm{Z} 2 \mathrm{pq}) / \mathrm{e} 2$

Where N0 denotes sample size, $\mathrm{Z}$ denotes $\mathrm{Z}$ value in a $\mathrm{Z}$ table, e denotes desired level of precision (i.e. the margin of error), p denotes the estimated proportion of the population which has attribute in question and q denotes 1-p.

In this case,

$\mathrm{N} 0=\left(1.96^{\wedge} 2 * 0.2^{*}(1-0.2)\right) / 0.05^{\wedge} 2=246$

Since the population under this study is small, the following formulae were used to modify the sample size:

$\mathrm{N}=\mathrm{n} 0 /(1+(\mathrm{n} 0-1 / \mathrm{N})$.

Where $\mathrm{N}$ is the new adjusted sample size, $\mathrm{n} 0$ is Cochran sample size recommendation.

Sample size was calculated as follows:

$246 /(1+(245 / 142)=90$

Total sample size of 180 small scale farmers was studied (90 small scale farmers who were the beneficiaries of each extension approach). 
Table-1: Respondents sampled per the corresponding villages.

\begin{tabular}{|l|l|l|l|}
\hline Name of Village & Population Size (N) & Sample Size (n) & Percent \\
\hline Oluti & 106 & 67 & 37.2 \\
\hline Ombo & 44 & 28 & 15.6 \\
\hline Lunga & 42 & 27 & 15.0 \\
\hline Malela & 38 & 24 & 13.3 \\
\hline Gul & 25 & 16 & 8.9 \\
\hline Kaila & 24 & 15 & 8.3 \\
\hline Magina & 5 & 3 & 1.7 \\
\hline Total & $\mathbf{2 8 4}$ & $\mathbf{1 8 0}$ & $\mathbf{1 0 0 . 0}$ \\
\hline
\end{tabular}

Source; One Acre Fund manual $(\mathrm{n}=180)$

\section{ANALYSIS}

\section{Statistical analysis}

\section{Descriptive statistics}

Descriptive statistics was based on the raw data obtained and researcher used the information to draw certain indices from it. The researcher used mean and frequency to show the findings.

\section{Inferential statistics}

Inferential analysis deals with various tests of significance for testing hypothesis that, effectiveness of selected extension approaches does not have statistically significant difference on levels of maize production. Independent sample t-test was used to compare the sample means to determine whether there was any statistical significance difference in levels of maize production due to the selected approaches. One way- Analysis of variance (ANOVA) was used to determine statistically significant differences between mean scores of the three groups; before and after project extension approach participation and conventional extension approach beneficiaries.

\section{ReSUlTS AND Discussions \\ General Respondents' Characteristics \\ Gender of the Respondents}

The largest number of the respondents were female at 62.2 percent female at 62.2 percent while men at 37.8 percent as presented in Table 2. Availability of time for women contributed to their dominance in this study. In addition, most males never participated in the interviews referring enumerators to the females who are considered as farms owners.

Table-2: Realigning of the frequency and percentage columns to be well aligned with the figures

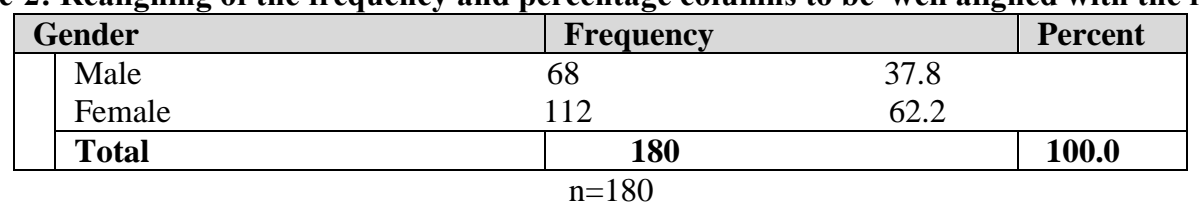

\section{Age of the Respondents}

The small-scale farmers within an age bracket of 31 to 45 years old registered the largest number at 51.7 percent and age group between 61-80 years recorded the least at 5 percent of the respondents as shown in Table 3 . This shows that mostly youths are engaged in maize production since they are young and energetic and can provide the needed labour during land preparation, planting, weeding, top dressing, harvesting and storage.

Table-3: Age distribution among respondents

\begin{tabular}{|l|l|l|l|}
\hline \multicolumn{1}{|c|}{ Age Range (years) } & Frequency & Percent \\
\hline \multirow{7}{*}{} & $18-30$ & 32 & 17.8 \\
\cline { 2 - 4 } & $31-45$ & 93 & 51.7 \\
\cline { 2 - 4 } & $46-60$ & 46 & 25.6 \\
\hline $61-80$ & 9 & 5.0 \\
\cline { 2 - 4 } & Total & $\mathbf{1 8 0}$ & $\mathbf{1 0 0 . 0}$ \\
\hline \multicolumn{4}{|c}{$\mathrm{n}=180$} \\
\hline
\end{tabular}

Education levels of the Respondents

Most respondents have primary level of education, with very few having attained higher level of education as shown in Table 4 which indicates 57.8 percent of respondents have attained primary certificate level of education and the least being university degree level at 4.4 percent.

Table-4: Distribution of Education levels of respondents.

\begin{tabular}{|l|l|l|l|}
\hline Level of Education & Frequency & Percent \\
\hline & University & 8 & 4.4 \\
\cline { 2 - 4 } Secondary & 51 & 28.3 \\
\hline Polytechnic & 17 & 9.4 \\
\hline Primary & 104 & 57.8 \\
\hline Total & $\mathbf{1 8 0}$ & $\mathbf{1 0 0 . 0}$ \\
\hline \multicolumn{2}{|c}{$\mathrm{n}=180$}
\end{tabular}

\section{Household size of the Respondents}

The findings in this study shown in Table 5 reveals that majority of the respondents have household size of 5 at 22.8 percent and the least being household size of 1 at 1.1 percent. 
Table-5: Respondents Household Size Distribution

\begin{tabular}{|l|l|l|l|}
\hline \multicolumn{2}{|c|}{ No. of household members } & Frequency & Percent \\
\hline 1 & 2 & 1.1 \\
\hline 2 & 4 & 2.2 \\
\hline 3 & 24 & 13.3 \\
\hline 4 & 33 & 18.3 \\
\hline 5 & 41 & 22.8 \\
\hline 6 & 39 & 21.7 \\
\hline 7 & 16 & 8.9 \\
\hline 8 & 11 & 6.1 \\
\hline 9 & 4 & 2.2 \\
\hline 10 & 6 & 3.3 \\
\hline Total & $\mathbf{1 8 0}$ & $\mathbf{1 0 0 . 0}$ \\
\hline
\end{tabular}

$\mathrm{n}=180$

\section{Farm size of Respondents}

Respondents own small land sizes at an average of 0.8097 hectares. The study also reveals that beneficiaries of project extension approach have relatively greater farm size of 0.7085 hectares under maize production techniques compared to beneficiaries of conventional extension approach with an average of 0.4049 hectares.

Table-6: Respondents Farm Size Distribution.

\begin{tabular}{|l|l|l|}
\hline Size & Mean & N \\
\hline Land & 0.8097 & 180 \\
\hline Project extension approach & 0.7085 & 90 \\
\hline Conventional extension approach & 0.4049 & 90 \\
\hline \multicolumn{2}{|c|}{$\mathrm{n}=180$}
\end{tabular}

Table-7: Respondents distribution regarding influence of selected extension approaches on level of maize production

\begin{tabular}{|l|l|l|l|l|l|}
\hline \multicolumn{4}{|c|}{} & Project Extension Approach & Conventional Extension Approach \\
\hline Response & Frequency & \multicolumn{2}{|c|}{ Percent } & \multicolumn{1}{|c|}{ Percent } & Percent \\
\hline \multirow{3}{*}{} & Yes & 125 & 69.4 & 64.8 & 35.2 \\
\cline { 2 - 6 } & No & 40 & 22.2 & 12.5 & 87.5 \\
\cline { 2 - 6 } & Neutral & 15 & 8.3 & 26.7 & 73.3 \\
\cline { 2 - 6 } & Total & $\mathbf{1 8 0}$ & $\mathbf{1 0 0 . 0}$ & & \\
\hline
\end{tabular}

\section{Levels of maize production}

Improvement of agricultural production among small scale farmers in the rural areas is an important factor in achieving household food nutrition and security. In order to achieve improved agricultural production, adoption of improved agricultural technologies is instrumental. This study revealed that maize yields have improved following the adoption of selected maize agronomic practices disseminated by either of the selected extension approaches with 69.4 percent of respondents acknowledging yields improvement.

Meanwhile, beneficiaries of project extension approach have recorded the highest positive yield response at 64.8 percent compared to conventional extension approach beneficiaries at 35.2 percent. This concur with Nin et al., [14], who realized that agricultural production growth in the developing world is a resultant of the adoption of improved agricultural production technologies. However, 22.2 percent of interviewed farmers realized no positive changes in maize yields with beneficiaries of project extension approach and conventional extension approaches represented by 12.5 and 87.5 percent respectively. Finally, 8.3 percent of respondents could not agree with any aspect of the approaches to having changed levels of maize yields with project extension approach beneficiaries at 26.7 percent and conventional extension approach at 73.3 percent as indicated in Table 7 .
Highest maize yields were recorded by beneficiaries of project extension approach at an average of $498.3 \mathrm{~kg}$ compared to $298.1 \mathrm{~kg}$ for the beneficiaries of conventional extension approach as shown in Table 3. Results also indicate a statistical significance difference between selected approaches at 0.05 alpha level $(\mathrm{t}=6.23, \mathrm{P}<.05)$.

Table-8: T-test analysis results for selected extension approaches on levels of maize production

\begin{tabular}{|l|l|c|c|c|c|}
\hline Categories of beneficiaries & N & Mean & Std. Deviation & $\boldsymbol{t}$-value & 2-tailed probability \\
\hline Project Extension approach & 90 & 498.2778 & 262.21310 & $6.23^{*}$ & $.000^{*}$ \\
\hline $\begin{array}{l}\text { Conventional Extension } \\
\text { approach }\end{array}$ & 90 & 298.0556 & 155.73078 & & \\
\hline
\end{tabular}

Legend: (*) Significant at the .05 alpha levels $\mathrm{n}=180$

There were significant differences at $\mathrm{F}=$ $60.656, p=.000$ through ANOVA on the levels maize yields realised following adoption of maize agronomic practices disseminated through selected extension approaches as shown in Table 9. 
Table-9: ANOVA Results on Maize yields

\begin{tabular}{|l|r|r|c|c|c|}
\hline Scores & Sum of Squares & \multicolumn{1}{|c|}{ df } & Mean Square & F & Sig. \\
\hline Between Groups & 4384611.296 & 2 & 2192305.648 & 60.656 & .000 \\
\hline Within Groups & 9650188.333 & 267 & 36143.027 & & \\
\hline Total & 14034799.630 & 269 & & & \\
\hline
\end{tabular}

Further, results show an existence of a statistically significant difference between the categories of respondents regarding maize yields with calculated P-value at 0.000 at 5 percent level of significance $(\mathrm{P}<0.05)$ between groups of before and after project extension approach participation. Similarly, beneficiaries of project extension approach and conventional extension approach results shows a statistically significance differences with a calculated Pvalue of .000 at 5 percent level of significance. However, there is no statistically significance difference in the level of maize production between before project extension approach participation and conventional extension approach beneficiary with calculated P-value of .089 at 5 percent level of significance $(\mathrm{P}>.05)$ as presented in Table 10.

Table-10: Analysis of variance results for selected extension approaches on levels of maize production

\begin{tabular}{|l|l|l|l|l|l|}
\hline \multicolumn{1}{|l|}{ (I) Group } & $(\mathbf{J})$ Group & Mean Difference (I-J) & Std. Error & Sig. \\
\hline \multirow{3}{*}{ LSD } & \multirow{2}{*}{1} & 2 & $-307.50000^{*}$ & 28.34040 & $.000^{*}$ \\
\cline { 2 - 6 } & 3 & $-107.27778^{*}$ & 28.33040 & $.089^{*}$ \\
\cline { 2 - 6 } & \multirow{3}{*}{2} & 1 & $307.50000^{*}$ & 28.34040 & $.000^{*}$ \\
\cline { 2 - 6 } & 3 & $200.22222^{*}$ & 28.34040 & $.000^{*}$ \\
\cline { 2 - 6 } & \multirow{2}{*}{3} & 1 & $107.27778^{*}$ & 28.34040 & $.089^{*}$ \\
\cline { 2 - 6 } & 2 & $-200.22222^{*}$ & 28.33040 & $.000^{*}$ \\
\hline
\end{tabular}

* The mean difference is significant at the 0.05 level.

Key: 1- Before project approach participation, 2- After project approach participation, 3- Conventional extension approach participation); I\&J- Farmers category; LSD- Least Square Difference.

\section{CONCLUSION}

Based on the results of the study the following conclusions are drawn: Farmers who adopted maize production technologies' disseminated through project extension approach as compared to beneficiaries of conventional extension approach besides having the same farm size recorded highest levels of maize production in terms of yields. Therefore, from the study findings project extension approach is more effective in disseminating selected production technologies meant for improving levels of maize production than conventional extension approach hence enabling it's beneficiaries realized improved maize yields as compared to conventional extension approach beneficiaries.

\section{ACKNOWLEDGEMENT}

This research received great support from a number of people who $\mathrm{i}$ am grateful to and remain indebted to. I would like to acknowledge Dr. Bunyatta and prof. Basweti with warm gratitude for their immense guidance and constructive criticisms in coming up with this paper may god bless you for your good work. Secondly, is to express my deepest gratitude sincerely to Kisii University and all my course work lecturers for their inspiration and insights throughout the course work as well as their valuable guideline and unique encouragement. Thirdly, is to thank the African Development Bank (AfDB) for granting me full scholarship to pursue my Msc in this renowned university. I also extend my heartfelt thanks to the One
Acre Fund organization and Ministry of Agriculture and all the farmers of East Seme Location who took their time in answering questions as per the interview schedule and availed credible information.

\section{REFERENCES}

1. Kenya Institute for Public Policy Research and Analysis (KIPPRA). (2013). Kenya Economic Report 2013: Creating an Enabling Investment for Competitive and Sustainable Counties. Nairobi. Retrieved from http://www.kippra.org/downloads/Kenya Economic Report 2013.pdf

2. Government of Kenya. (2012). National Agricultural Sector Extension Policy (NASEP). Nairobi.

3. Swanson, B. E., Bentz, R. P., \& Sofranko, A. J. (2007). Improving agricultural extension. A reference manual. Sustainable Development.

4. Sanchez. (1997). Adoption and continued use of improved maize seeds: Case study of Central Ethiopia. African Journal of Agricultural Research, 5(17): 2350- 2358.

5. Anandajayasekeram, P., Puskur, R., Workneh, S., \& Hoekstra, D. (2008). Concepts and practices in agricultural extension in developing countries: A source book, 83-100.

6. Milu, M., \& Jayne, T. S. (2006). Agricultural extension in Kenya: Practice \& Policy Lessons (Vol. 26). Nairobi, Kenya.

7. FAO. (2015). The State of Food and Agriculture 2015. Social Protection and Agriculture: Breaking the Cycle of Rural Poverty. Sofa. Rome. Retrieved 


\section{from}

http://www.fao.org/documents/card/en/c/ab825d80c277-4f12-be11-fb4b384cee35/.

8. Swanson, B.E., Sofranko, A.J., \& Bentz, R.P., eds. (1997). Improving agricultural extension. Rome, Food and Agriculture Organization of the United Nations.

9. Yaron, D., Dinar A., \& Voet, H. (1992). Innovations on family farms: The Nazareth Region in Israel.

10. Ellis-O’Quinn, A. (2012). An Ex Post Facto Study of First-Year Student Orientation as an Indicator of Student Success at a Community College. Inquiry, 17(1), 51-57.

11. Wiersma, W. (2009). Introduction to research methods in education. British Journal of Educational Technology (Vol. 40).

12. Kothari, C. R. (2012). Research Methodology: An introduction. Research Methodology: Methods and Techniques, IX, 418. http://doi.org/Goddard, W. \& Melville, S.

13. Cochran, W. G. (1963). Sampling techniques. 2nd.Edition

14. Nin, A., Arndt, C., \& Precktel, P. (2003). Is agricultural productivity in developing countries really shrinking? New evidence using a modified nonparametric approach. Journal of Development Economics, 71, 395-415.

15. Maunder, A.H. (1973). Agricultural Extension: A Reference Manual. Italy, Rome: FAO, Publication.

16. Morris, M. (2001). Assessing the benefits of international maize breeding research: An overview of the global maize impacts study. Part II of the CIMMYT 1999-2000 world maize facts and trends.
17. Karanja, D. D. (1990). The rate of Return to maize research in Kenya: 1955-88. M. Sc. Thesis, Department of Agricultural Economics, Michigan State University, East Lansing, Michigan.

18. Mwabu, G., W. Mwangi., \& H. Nyangito (2007). Does Adoption of Improved Maize Varieties Reduce Poverty? Evidence from Laikipia and Suba Districts in Kenya. Productive Sector Division, Kenya Institute of Public Policy Research and Analysis. KIPPRA Discussion Paper No.7, Nairobi, Kenya.

19. Kolawole, G.O. (2014). Effect of time of poultry manure application on the performance of Maize in Ogbomoso, Oyo State, Nigeria. Journal of Applied Agricultural Resource, 6:253-258.

20. Alene, A.D., Menkir, A., Ajala, S.O., BaduApraku, B., Olanrewaju, A.S., Manyong, V.M. and Ndiaye, A. (2009). The economic and poverty impacts of maize research in West and Central Africa. Agricultural Economics, 40(5):535-550.

21. Nielson, R.L. (2001). "Stand Establishment Variability in Corn". http://www.agry.purdue.edu/ext/pubs/AGRY-9101_v5. (2001).

22. Spasojevic. (2014). Effects of different cropping systems and weeds management methods on free energy and content of pigment in maize. Pesticides and phytomedicine, 29: 45-54.

23. Oudejan, J.H. (1991). Agro-pesticide properties and functions in integrated crop production. United Nations Economic and social commission for Asia and the Pacific.

Cite This Article: Otieno Stephen Otieno et al (2021). Comparative Analysis of the effectiveness of Project and Conventional Extension Approaches on Levels of Maize Production among Smallholder Farmers, A Case of One-Acre Fund in Seme Sub-County, Kenya. East African Scholars J Agri Life Sci, 4(3), 67-74. 